\title{
TRADITIONAL BELIEFS SEBLANG THE BEHAVIOR OF THE OSING SOCIETY OF BANYUWANGI DISTRICT EAST JAVA PROVINCE
}

\author{
Agus Mursidi \\ Department of History Education, Faculty of Teacher Training and Education, PGRI \\ University of Banyuwangi, Indonesia \\ Jl. Ikan Tongkol No 1 Gedung FKIP Universitas PGRI Banyuwangi kota Banyuwangi. \\ Email: Agusmursidi78@gmail.com
}

\author{
Harwanti Noviandari \\ Department of guidance and counseling, Faculty of Teacher Training and Education, \\ PGRI University of Banyuwangi, Indonesia \\ Jl. Ikan Tongkol No 1 Gedung FKIP Universitas PGRI Banyuwangi kota Banyuwnagi. \\ Email: sittihafsahwaode@gmail.com
}

Article received March 18 $8^{\text {th }}, 2021$; Article revised April 27 $7^{\text {th }}, 2021$; Article approved May $8^{\text {th }}, 2021$

\begin{abstract}
Banyuwangi has various cultural and traditional activities as well as art. One of them is the seblang tradition which is only practiced by the Osing community in Banyuwangi, that is, Bakungan Village and Olehsari Village in Glagah District, Banyuwangi Regency. This research was a qualitative research with a phenomenological approach with 15 informants consisting of community leaders, government, members of community. The results of this study indicated that belief in implementing customs generated the behavior from the results of self-perception which are supported by social perceptions aimed at cleaning the village and rejecting reinforcements. The community's belief in the Seblang tradition is still ingrained and carried out well so that it forms community behavior if it is not carried out, disaster will take place. In the self-perception of the Bakungan and Olesari community, the assumption is that the community members do not celebrate it, they will be ostracized by other communities. However, in its development, the role of government is in hegemony of the community so that custom continue to develop into one of the contestation of customs and tourism.
\end{abstract}

Keywords: traditional beliefs, seblang, behavior, the osing society.

\section{INTRODUCTION}

I ndonesia with symbols of unity in diversity clearly illustrates that this country has a variety of shades of race, ethnicity, religion, culture, and art. Ethnic diversity can give birth to various cultures. These cultures bring their own uniqueness and uniqueness to the people (Muslim, 2016: 221-230). For example, the customs that are carried out will be different even though they are still in the same area. Rifa'i states that culture is the result of thoughts, beliefs, and values that have been passed down from generation to generation and used by society at certain times, to deal with and resolve various problems that arise from time to time, both in individual and community life (Susanti, 2013).
Culture becomes a symbol or certain characteristic for an area (As'ad, dkk, 2012). This culture can be in the form of regional arts, religious ceremonies or rituals. Some examples of culture as a regional identity, namely, in Bali we often encounter the Ngaben tradition, Balian Rituals, and so on. In Blitar, there is a ritual called the Grebek Pancasila ritual, and the ritual of bathing Mbah Pradah, a sacred gong which is believed to be a blessing. In addition, in Maluku, there is a cultural art of the Cakalele dance which has a background because it is a former colonialist.

Traditional ceremonies are social activities that involve all members of the community in order to achieve mutual safety (Muslim, 2016: 259-274). Traditional ceremonies are an integral part of the culture 
of the people who support it. Its preservation is only made possible by its function in the life of the common people. This traditional ceremony will become extinct if it has no function at all. As in the area of Banyuwangi, which is inhabited by the Osing tribe, known by their unique arts, rituals and culture, one of which is the traditional "Seblang" ritual. Seblang is the forerunner of the Gandrung dance which is also known as the mascot of Banyuwangi City. Gandrung is a performance art that is presented with musical accompaniment that is typical of a blend of Javanese and Balinese culture. The dance is performed in the form of a solo, or in pairs between women, the gandrung dancers and men, pemaju, or shortly known as "paju". The dance is Banyuwangi Gandrung which held as a manifestation of the community's gratitude after every harvest.

Art in its various forms of expression can be used as a mirror of culture, because it always moves together with the hearts of the people. Types of art in a social context have specific supporting groups with different functions. There are those that function only as entertainment without having religious value, but there are also those that have religious value in the sense that their implementation is accompanied by a certain belief or beliefs.

Seblang art is one example of art that is believed to be of sacred value in the Osing Olehsari and Bakungan tribal communities as a pre-Hindu cultural heritage. One of the characteristics is human belief in 3 spirits and supernatural powers to control something by using religious means (Koentjaraningrat, 1984). Seblang is an annual religious ritual performance held by the Osing tribe in two villages of Glagah District, that is, Olehsari and Bakungan villages. The implementation procedures in these two villages are very different even though the expected goals are the same. The ritual of Seblang in Olehsari is carried out after Eid al-Fitr for seven consecutive days, while in Bakungan it is only held one night after Eid al-Adha. Dancers in Olehsari are performed by girls who are under 13 years old, while in Bakungan it is performed by women over 70 years old. Seblang Olehsari and Seblang Bakungan are of a couple. Seblang Olehsari is called the female Seblang, while Seblang Bakungan is the male Seblang. This difference can be seen from the form of dance movements. In Bakungan dancers demonstrate war theatrical movements by carrying weapons in the form of kris and more manly movements. Whereas in Olehsari the movements are not patterned like a theatrical, although they are agile but Seblang Olehsari tends to be more graceful.

The Seblang ceremony for the Bakungan and Olehsari Banyuwangi community is a means of communication with God and with their ancestors. In addition to communicating using verbal language, it is also through the art of movement in the form of dances so that the Seblang ritual is called the Seblang dance. The Seblang ritual or dance is held with several purposes, namely as a clean village "slametan", 4 attempts to refuse reinforcements, inviting fertility, respecting ancestors, expressing gratitude and others. The Seblang dance is also accompanied by Javanese "gending" and Banyuwangi original "gending" as an addition to the passion of the dancer who is waddling unconscious trance.

The phenomenon that arises in the effort to provide the correct formulation of trance is the fact that the simplicity of the cultural level of a society, the more visible the tendency to believe in forces that are not real, but are a reality that exists around the community and nature (Adibah, 2019).

This unreal power is sometimes considered superior to nature and humans themselves. In fact, it is so feared because it can endanger their lives, in the form of calamities. Thus, they feel the need to worship in the form of a ceremony in an effort to reject it and protect or maintain permanence of life. Apart from using verbal language in the form of mantras, the ceremonies also use non-verbal language in conveying the. On the basis of the phenomena described above, this research is important to carry out in order to determine the uniqueness of the Seblang tradition of the Osing Tribe in Bakungan and Olehsari Villages, Banyuwangi Regency which can be seen from the perceptions and dynamics of the local community behaviors

\section{Public Trust}

Trust will have positive and negative impacts on society according to individual and social beliefs (Priansa, 2017). Trust is in 
conducting a transaction relationship based on a belief that the person he trusts is in accordance with what is expected (Priansa, 2017). Trust is the object, attribute, and benefit of the knowledge that consumers have and all the conclusions that consumers make (Priansa, 2017). Trust is based on expectations for the good behavior of others from the psychological area which is a concern for accepting what it is (Priansa, 2017). Trust is an appropriate expectation in an environment full of uncertainty which is an assessment of a person's relationship with other people who will transact (Priansa, 2017). So that traditional beliefs or beliefs inherent in the people, such as the origin of the "seblang" dance in Bakungan village, still have high trust among the people. One of the examples is the members in Bakungan village remain believe in that the calamities will happen and hit if this dance is not performed, because this dance is considered to have supernatural powers by the communities around Bakungan Village.

\section{Oral Tradition}

Traditions are classified into three groups, one of which is partially oral tradition. This word of mouth can be in the form of beliefs among its people. Partially oral oral traditions take the form of oral and non-verbal elements including (a) traditional beliefs, (b) folk games, (c) customs, (d) ceremonies, (e) folk theater, (f) folk dance, and (g) people's party (Sukatman, 2009). Traditional beliefs or beliefs attached to the people, such as the origin of the "seblang" dance in Bakungan village, still have high trust among the people. For example, they (the Using community) in Bakungan village still believe in the calamities that will happen and hit if this dance is not performed, because this dance is considered to have magical powers by the Using community around Bakungan Village.

Myth is a people's prose, which is considered to have really happened and is considered sacred by the story owner and can lead to trust among the people about things that don't make sense related to their transmission through oral speech (Nasrullah, 2018). Trust has to do with a view of how the world operates. Beliefs can be in the form of views or interpretations of the past regarding explanations of the present, predictions about the future, and it can also be based on common sense (Maran, 2007). This section will explain further about the meaning of myths, types of myths, and the function of myths.

\section{Social Behavior}

Social behavior consists of two words; behavior and social. According to Syamsul Arifin, behavior is an act and a word that can be observed by others. 53 Meanwhile, social means with regard to society or the conditions contained in an environment. Several dimensions of social behavior are:

1. Physical that can be observed, described and recorded in terms of frequency, duration and intensity.

2. Space is a behavior that has an impact on the environment in which the behavior occurs.

3. Time is a behavior related to the past or the future.

Social behavior is a public activity that can be observed either directly or indirectly by the community. Social behavior can be interpreted as a response by a person to stimuli from outside the subject (Arifin, 2015). Social behavior is formed from the learning process which usually reacts spontaneously. Social behavior can be demonstrated through feelings, actions, beliefs and respect for others. In general, social behavior is an activity carried out by someone who can be observed, but not infrequently, behavior can only be understood. There are several definitions of behavior, including definitions by experts:

1. Ivan Pavlov is a psychologist who argues that behavior is an activity that can be carried out by a person and can be observed from the outside.

2. Sigmund Freud defines behavior as the result of human interaction such as the Id, Ego, and Super Ego (Sukendar, 2017).

3. Krech, Crutchfield and Ballachey stated that a person's social behavior can be seen from their attitudes, actions and words in responding to others which are influenced by environmental factors (Suciati, 2016). 
Social behavior is identical with a person's reaction to others which is shown by feelings or actions towards others. Humans in fulfilling their daily needs cannot do it alone but they need help from others. The community is expected to work together, respect each other, do not interfere with the rights of others, and tolerant in social life. A person's social behavior is shown when interacting with other people. People who behave well reflect their kindness in the socialization process, so they can be said to be social people, while people whose behavior does not reflect the socialization process are called non-social. A person's social behavior is influenced by various internal and external factors. Even though social behavior is influenced by external stimuli, it is true that within the audience, it is free to determine its behavior. The reflected social behavior depends on the readiness of the audience to face the influence of the Cultural Activities which are held in traditional parties.

There are several things that influence social behavior. According to Baron and Byrne, there are four categories that can shape a person's social behavior, namely:

a. Behavior and characteristics of other people. If the audience is more likely to hang out with people who have a polite character, then there is a high probability that they will behave politely in their environment or vice versa. This behavior occurs because someone learns from the environment.

b. Cognitive processes. Cognitive is one of the important aspects of a person because it contains ideas, beliefs and considerations that form the basis of a person's social awareness that affects their social behavior. Learning is a way of knowing someone to act according to existing norms.

c. Environmental factors. The environment is very influential on a person's behavior to meet human survival, so they must help each other. Associating with the community can influence their behavior either directly or indirectly.

$\mathrm{d}$. Independence. Independence is a person's ability to be able to solve problems without special interference from other people (Gerungan, 2004). The behavior that is in a person will arise because of an impulse from within the self, not because of the influence of other people. People who have independence will tend to make decisions without the help of others.

\section{RESEARCH METHOD}

Research design is an attempt to plan certain possibilities broadly without showing exactly what will be done in relation to their respective elements (Agur Mursidi, 2020). The research in this proposal used a qualitative research design. According to David Williams (Moleong, 2015), qualitative research is the collection of data in a scientific setting using scientific methods, and is carried out by researchers who are scientifically interested. This qualitative research method is used for several considerations. First, it is easier to adjust qualitative methods when dealing with multiple (multiple) realities. Second, this method directly presents the nature of the relationship between the researcher and the respondent. Third, this method is more sensitive and adapts itself to a lot of sharpening the joint influence on the value patterns faced.

Qualitative research is a research procedure that produces descriptive data in the form of words, either spoken or written, from people and observable behavior. Qualitative research is also referred to as naturalistic research. Qualitative research is a research that has the character or characteristics, that the data is stated in a natural state or as it is (natural setting), without changing in the form of symbols or numbers (Moleong, 2015). The type of research used in this qualitative research is phenomenology, which is a job of describing a culture with the aim of understanding a native's perspective, the relationship with life to get the view of their world (Sugiyono, 2015).

\section{DISCUSSION}

\section{Society Beliefs (Osing Bakungan And Olehsari)}

Art is the creation of all human thoughts and behaviors that are functional, aesthetic and beautiful so that they can be enjoyed with the five senses, namely sight, smell, taste, touch and hearing. In terms of its manifestation, art is divided into three types, namely fine arts, literary arts and performing 
arts as well. Seblang art is included in the type of performing arts because the elements of performing arts are time, space, the artist's body and the artist's relationship with the audience. In order to maintain art which is a form of culture, the government is trying various ways of making policies to explore and revive traditional arts.

Traditional arts are influenced by the daily life patterns of the local people. Likewise, the art of Seblang is carried out by the Bakungan community to carry out the traditional seblang tradition. Seblang art is a form of gratitude to God and also respect for the ancestral spirits of the Bakungan and Olehsari people. This aims to find out:

a. The origin of Seblang art in Bakungan Village.

b. Implementation of seblang arts in Bakungan Village.

c. The moral values contained in the seblang art in Bakungan Village.

The practicing community in Bakungan Village has a close relationship to God. The relationship between man and God is manifested in a form of trust. The practicing community feel that as God's creation, humans must respect God by always diligently carrying out worship and praying in order to get a good life.

\section{Myth of Practicing Community}

The world of myths that includes primitive (ancient) cultural realms is still attractive to us. In addition, the mystical world also has an influence on the people. One of them is that Javanese society cannot be separated from mystical things. One of the mystical things can be in the form of myths, namely sacred stories that are difficult to believe in their existence and are abstract about the good and the bad. In every activity it is often based on certain myths.

Myths can be used as guidelines and directions for behavior in society to become a wiser person because myths provide a picture of the good and bad traits in life. Therefore, myths can make people believe in them, become obedient and obedient to the teachings they adhere to, so as to create awareness and behavior in social life. With the existence of myths, humans can have limits according to the consequences.

The Bakungan area used to be a wilderness with many daffodils and in the middle there is a large tree called "NOGO SARI". The people around the area work voluntarily to clean the lily plants. After all the lilies in the area have been cleaned, the "NOGO SARI" tree remains, which is still standing. Many people around the Bakungan area want to cut down the "NOGO SARI" tree. In fact, it was not the tree that was cut down. On the contrary, the bad impact was received by the people who wanted to cut the tree. It is death. In the end, there was someone who had magic named Mbah Djoyo. Mbah Djoyo tried to communicate with the Nine Danyang (guardian spirits) in the "NOGO SARI" tree. Finally, a decision was agreed upon that the Nine Danyang would be willing to leave, but before, there were conditions that had to be met. Every time there was a clean sub-village there had to be an art performance regarding to spirits and this art called "seblang".

\section{Social Sanction Against the Seblang Bakungan Tradition}

Throughout the course of history, the life of art as part of culture never escapes changes. The change may occur due to development of mindset and human understanding of nature and things around it, or maybe because of friction with other elements that are outside the human. In line with the passage of time, the rituals are in the ebb and flow of cultural dynamics. The social and cultural values of the people in Bakungan Village are very close.

Bakungan Village is included in the village group whose culture is well preserved because all elements of its citizens always provide and support something and a sense of selfless zeal, especially when it comes to ritual activities. The attachment and consciousness between man and the universe, and creating a balanced relationship between humans and nature, so that a state is built safe, secure and protected. This at the same time can convey thoughts among the Bakungan community which there will be one social unity.

Performing and celebrating seblang rituals for the Bakungan Community does not only as a guide to the ancestral heritage, but also to protect and carry out the mandate of the next generation, especially those who have a dancer's lining. This seblang generation of descendants is the party or 
community that is the most responsible for the extensibility of the seblang ritual.

\section{Society Behavior Against the Seblang Bakungan Tradition}

Seblang art is one example of art that is believed to be of sacred value in practicing community of Bakungan as a PraHindu cultural heritage. The Seblang ceremony for the people of Bakungan Village is a means of communication with God and with their ancestors. This art in addition to convey messages related to religion is also in terms of relationships or interactions between people. The functions that exist in seblang according to the beliefs of the community are as follow:

\section{a. The village}

In the village clean salvation, as reflected in its name, all residents in the village get involved. Clean up the village or clean the hamlet once a year, that is, on the interlude or Shawwal month in the Hijri calendar. This village salvation as a tradition that has been popular in Java is also an annual tradition of the community who are still well preserved. The implementation in every village has different times. For events of this kind, see this at Bakungan Village Mojopanggung, Giri District in the month of Dzul Hijjah. In the village cleaning, spiritually the community cleanses itself from evil, sin, and all that causes misery.

\section{b. Fertility Invites Agrarian}

Culture or all lives that rely on luck from natural products still very much characterizes the life of the people of Olehsari Village. In terms of agriculture, they are still very strong with traditional farming patterns. This means that the planting, maintenance, till processing of the land still used traditional tools and systems, such as plowing the fields with cow's, which still play an important role. Likewise, when harvesting, the ekrak (reaper) and sickle (sickle) are still dominant.

\section{c. The Disease Treatment Facility}

Seblang Art for the people of Bakungan Village and its surroundings also functions as a means of treatment. This aspect can be witnessed during the ceremony, precisely at the beginning after the dancer demonstrates several pieces of piece scenes, namely when the dancer is resting or sitting on a chair. On that occasion the spectators and the actors one by one handed a glass filled with water through the companion to the dancer.

\section{d. Ancestral Respect}

The Seblang ceremony which is full of magical nuances is a manifestation or realization of people's respect for the spirits of their ancestors. This manifestation can be observed in the dance offerings when the village held Mubeng (traveling) on the last day. In the procession from the center of the ceremony, the dancers are followed by the Pesinden, musicians and the community, led by the obedient shaman walking around the village. After they performed the ceremony at the village hall, the perpetrators proceeded to the grave, which is the place where the ancestors of the Bakungan Village community were buried.

\section{The Process of the Traditional Dance of The Seblang and The Bakungan}

Residents of Bakungan Village have long held the Seblang Ritual to be kept away from all distress, they perform rituals all night long, which is a dance ritual performed by an elderly woman. This tradition already existed since 316 years ago. It is said that those who pioneered the Bakungan village comes from Bali. Bakungan is one of the names of many plants that live on that place. In the past, Bakungan was a wilderness that was overgrown with daffodils.

Seblang comes from the ancient Osing language which means the loss of every troubles. This ceremony was preceded by a mass salvation that was held just after sunset. All residents sit in front of their respective houses while offering tumpeng which consists of several types of special foods. Among them, chicken pecel which is chicken meat mixed with young processed coconut. A day before, several community leaders performed a ritual asking for permission at 'buyut's grave Witri '. He is believed to be the ancestor of the 'Kelurahan Bakungan' community. In this place, people ask for prayers while taking holy water. This water will later be used by Seblang dancers for purification and distributed to all villagers.

Before eating tumpeng, the shaman reads special prayers using Osing language. Its contents ask all the rulers of the universe 
to give mercy to them as the whole society. The atmosphere felt mystical when the smell of incense is sprinkled shamans scattered all over the arena. After that, the traditional leader beat the kentongan many times as a sign of the completion of the tumpengan ceremony. Citizens welcome with the recitation of the holy Koran. After that, all the residents ate their tumpeng. During the salvation, all family members gathered in his yard.

Previously, the male residents along with the youths walked around the village while carry a torch. This ritual is meant to ward off evil spirits who will disturb the village. They recite the holy verses of the Koran. Around 19.30 at night, the Seblang ritual begins. This event begins with calling the spirits who will possess the dancer's body. After being given a special spell, the dancer is in a trance. This dancer is a descendant of Witri's great-grandmother who is believed to be an ancestor of the Bakungan people.

\section{Profession Ritual Tradition of Seblang Bakungan}

As with other rituals, in detail the Seblang Bakungan dance has several stages before reaching the peak ritual. This is the sequence of rituals that must be carried out:

a. Seblang dancers do grooming and wear their dance clothes. On the body and face are covered with a kind of fine yellow stone flour (commonly called atal) mixed with water. Then the dancer goes walking towards the arena with several female singers and owner's wishes.

b. In this second stage, the dancer is worn various decorated crowns flowers of various colors. Not to forget, the dancers hold the nyiru with their hand. Then there was an old woman who closed the dancer's eyes with her hands. After that there is the handler who burns the incense as well cast a spell to summon the known dhanyang (village guardian spirit) with the names of Buyut Kethut, Buyut Jalil, and Buyut Rasio in order to be blessed the Seblang performance. When the nyiru held by the Seblang dancer, they would fall, then being in a trance alias. c. The third stage is the stage of selecting songs to accompany the dancer. Sometimes, the song played is not approved by the trance dancer. If the dancer agrees, then he will stand up and dance gracefully counterclockwise. If he disagree, he wouldn't stand up as well by giving a signal for the accompanist to play another song. Sometimes, at times pauses in song selection and the dancer resting, also come along a ritual involving cockfights.

d. After the dance ritual stopped for a moment, there were several beautiful girls in kebaya holding a dirma flower which is a colorful flower that is believed to bring blessings. Then this flower is given to the audience, then the audience giving a small amount of money.

e. This stage is called tundik and some call it Ngibing, which is the time at which the dancer invites the audience to join in dancing. How to choose an audience is unique, namely the Seblang dancer throwing sampur at the audience. Who got the sampur must dance with the Seblang dancers. The atmosphere become crowded and full of laughter as the audience ran scattered to avoid the sampur.

f. This is the culmination point of the Seblang ceremony. When the accompanist plays a song called Candradewi which played fast, the dancer also spins quickly. Then the dancer fell down and lay on his stomach. At this time the officer returned asking for alms from the audience.

After the performance, there is another ritual that will not be felt if it is not followed. The ritual is an event to scramble agricultural product offerings which were hung in several areas of village hall office. There are durian, rice, avocado, soursop, banana and even coconut.

\section{Public Perception of the Seblang Olehsari Tradition}

In order to maintain art which is a form of culture, the government is trying various ways of making policies to explore and revive traditional arts. This arts are influenced by the daily life patterns of the local people. Likewise, the art of Seblang is carried out by the Olehsari community to 
carry out the traditional Seblang tradition. Seblang art is a form of gratitude to God and also respect for the ancestral spirits of the Olehsari people. This aims to find out:

a. The origin of Seblang art in Olehsari village.

b. Implementation of Seblang art in Olehsari Village.

c. The moral values contained in the art of Seblang in Olehsari Village.

The practicing community of Olehsari village has a close relationship to God, the relationship between man and God is manifested in a form of trust. The practicing community feels that as God's creation, humans, must respect God by always consistently carrying out worship and praying in order to get a good life.

\section{The Myth of the Seblang Olehsari Tradition}

Myths can be used as guidelines and directions for behavior in society to become a wiser person because myths provide a picture of the good and bad traits in life. Therefore, myths can make people believe in them and become obedient to the teachings they adhere to, so as to create awareness and behavior in social life. With the existence of myths, humans can have limits according to the consequences.

Seblang is an annual religious ritual performance held by the Osing tribe in Glagah District, namely Desa Olehsari. The procedures for the implementation of this village are very sacred to perform rituals. Starting from the dancers, the time of implementation and also the process. In Olehsari, the Seblang ritual is carried out after Eid al-Fitr for seven consecutive days and dancers in Olehsari are performed by girls under 13 years old.

Seblang ceremony for the people of Olehsari Village is a means of communication with God and with their ancestors. In addition to communicate using verbal language, it is also through the art of movement in the form of dances so that the Seblang ritual is called the Seblang dance. This Seblang ritual or dance is held with several purposes, namely as a slametan, clean village, an antidote to repelling reinforcements as well as inviting fertility, respecting ancestors, and expressing gratitude to the creator.

\section{Community Impact on the Seblang Olehsari Tradition}

The village belongs to the social group whose culture is well preserved because all elements of its society always provide and support something and a sense of selfless zeal, especially when it comes to ritual activities. The attachment and consciousness between man and the universe, and creating a balanced relationship between humans and nature, so that a state is built safely, secure and protected. This can simultaneously convey thoughts between the people of Olehsari Village, so that there will be one social unity.

Performing and celebrating seblang rituals for the people of Olehsari village does not only as a guide to the ancestral heritage, but also to protect and carry out the mandate of the next generation, especially those who have a dancer's drop line clear. The generations of descendants of this seblang are the parties or the community which most responsible for the continuity of Seblang ritual. The existence of this ritual which has rooted strongly in the minds of the people of Olehsari Village, make it also as a bond in a sense of belonging to each other and diversity in any case.

Banyuwangi's products of local cultural have undergone a long process. Throughout the history of Blambangan as the last Hindu work in the eastern tip of Java Island, because before it became part of Majapahit operation, Blambangan was never separated from the target of other kingdoms that were interested in it. Geographical conditions are strategic and fertile. Link to conquest by other people's kingdoms causes society to have its own cultural patterns as a multi-ethnic society which capable of cultivating in cultural diversity with the existence of this ritual. People especially of Olehsari Village will find it easy in recognizing and memorizing anyone from the village which is one area of the Osing community.

\section{Community Behavior Against Seblang Olehsari Tradition}

Seblang art is one example of art that is believed to be of sacred value in the Osing Village community of Olehsari as a PraHindu cultural heritage. Seblang ceremony for the people of Olehsari Village is a means of 
communication with God and with their ancestors. Thus, this art in addition to conveying messages related to religion is also in terms of relationships or interactions between people. The functions that exist in seblang according to people's beliefs are as:

a. The village

In the village clean salvation, as reflected in its name, all residents of the village got involved. Cleaning the village or the hamlets once a year, that is, on the interlude or Shawwal month in the Hijri calendar. This village salvation on the side as a tradition that has been popular in Java is also an annual tradition of the practicing community which is still well preserved. The implementation in every village has different times for a similar event. This can be seen Olehsari Village on Eid Al-Fitr. In doing village cleaning, spiritually society cleans itself from evil, sin, and everything that causes misery.

b. Fertility Invites Agrarian

Culture or all life that relies on luck from natural products still very much characterizes the life of the people of Olehsari Village. In agriculture, they are still very strong with traditional farming patterns. This means that the planting, maintenance, till processing of the land keep on using traditional tools and systems, such as plowing the fields with cows' power, which still play an important role. Likewise, when harvesting, the ekrak (reaper) and sickle (sickle) are still dominant.

c. The Disease Treatment Facility

Seblang Art for the people of Olehsari Village and its surroundings also functions as a means of treatment. This aspect can be witnessed during the ceremony, precisely at the beginning after the dancer demonstrates several pieces of piece scenes, namely when the dancer is resting or sitting on a chair. On that occasion the spectators and the actors one by one handed a glass filled with water through the companion to the dancer.

d. Respect for the Ancestors.

Seblang ceremony which is full of magical nuances is the manifestation of or the realization of people's respect for the spirits of their ancestors. This embodiment can be observed in the dance offerings when the village mubeng (traveling) on the last day. On the procession from the center of the dancer ceremony is followed by the singer, musician and the community led by the accursed shaman walking around the village. After performing a ceremony at the village hall, the perpetrators proceed to the grave, which is the place where the ancestors of the Olehsari Village community are buried.

\section{Seblang Olehsari Traditional Dance}

According to records in a historical book in Olehsari Village, Seblang was never held between 1943 and 1956. For the people of Olehsari, the absence of a Seblang event is feeling lost. Pageblug occurs, crops fail a lot and disease attacks on livestock and humans are inevitable. So, in 1957 the event started again. It is said that the atmosphere recovered and prospered.

\section{Profession of Seblang Olehsari Tradition}

Still in the atmosphere of Eid, in Olehsari Village (about $5 \mathrm{~km}$ west Banyuwangi City) held the annual Seblang event. Actually, it was not difficult to find the location because from a distance the gamelan music can be heard, Ngelangut, as if calling anyone to come. Even though the procession held on a pretty hot afternoon, the surrounding area has been crowded with people who will follow the Seblang event. In the past, it was always among the crowd that later opened a path of unseen guests who ride horses which also provided empty chairs. There is no one dared to step on the lane or occupy that chair, due to occult guests. In the center of the ceremony, there is a pole in the form of a fresh sugarcane stick to it. On the side of a bollard is firmly planted Great Umbrella. Apart from serving as a Music Player venue, it is also an expression of Yoni, namely the center of the metaphysical ceremonial activity.

In the west, no less than 8 (eight) middle-aged women acting as a singer (sinden) sitting in a hut without walls, ready to accompany the Seblang Dancer. In the hut with the roof of the palm leaves, hanging dozens of fruits and Poro-Bungkil (crops) which are symbolic of the prosperity of the village. Soon a girl who was dressed strangely appeared. A face with fringed fringes of young banana leaves is led by a middle-aged woman, accompanied by dozens of people heading to the center of the ceremony. Salwati (16 years), the dancing girl is slowly led and seated near the prapen four billowing incense smoke. 
A shaman or oldest handler, Mbah Asnan (70 years), appears turning the small nyiru on top of the censer while muttering to read the spell. Suddenly the little copy was pushed towards Salwati. When Salwati accepting nyiru, she immediately fell and unconscious. Accompanied by the handlers of 5 (five) people, consisting of 3 (three) men and 2 (two) women whom are elderly. Salwati became a kejimen (read: in-trance) and danced lumbered beautifully. The opening gending for Seblang Lokento was heard then Salwati continued to dance around the $7 \times 7$ meters arena around the pillars and umbrellas. "Seblang yo Lokento sing dadi encakono" was sung repeatedly by the singersongwriter with great enthusiasm. Eyes closed, dancer occasionally like inviting the audience to joke by wagging his scarf. The crowd gave their spirits with jokes. The dancer also welcomed the sweet joke with the moves of their beautiful hips.

While the choir group sang the song of Kembang Dirmo, at that time Arrangements of various colored flowers, consisting of 5 (five) to 7 (seven). The flowers are arranged in a stick similar to satay, sold to the audience. Then the young people to buy it because reportedly lucky enough for business amorous love. Another scene which is also interesting is the Ngibing attraction. This occurs on the third day and so on from 7 (seven) days of Seblang performance. The body of Seblang dancer is lifted and placed on a table available by the handlers, so it appears taller than the audience. Then the dancer threw sampur towards the audience. Anyone who gets hit by the scarf (usually male) must be willing to dance together with the Seblang dancer. At the event which is quite attractive, once someone finishes ngibing with a Seblang dancer, it continues repeatedly for others turn.

Surprisingly, when dusk fell, there was a scene that was quite touching. Seblang dancer seemed to be showing his joy when the gending "Chondro Dewi" sung. With the joy, the Seblang dancer reaches the peak of climax dance. Because of this, he became exhausted and then fell unconscious. But miraculously, the song Erang-groans echoed, fantastically the power of that sad song as if reviving the dancer from fainting. According to some source, reviving from a stupor is a tough job for "Curse" (handler) who is the mediator with the spirit. It must be done extra carefully, because it is a difficult and dangerous job. If it is not succeed, the dancer can lose his life.

Finally, when the Sun had almost disappeared behind the Ijen Mountains, echoed the closing song which reads: "Sampun Mbah Ktut sare sampun osan", whose invitations are muleh-muleh. "The meaning is more or less like:" Never mind Mbah Ketut, the event is over, visitors will already go home. "That's it repeated 10 times, then the Seblang dancer seemed to regain consciousness as if someone woke up from his sleep. There was a look of confusion in the color of the dancer. Every now and then, Salwati uncovers the fronds of leaves that are staring at her face, she is pale even till the next day she had to dance again until she had completed the 7 (seven) days.

Watching Seblang in Olehsari this year, there found one interesting thing. It is well known as the procession of nominating Seblang dancer candidates. It was not spared aspects of supernatural powers. Every month of fasting before Lebaran, it takes a turn for a housewife who is usually 30 (thirty) years old up in a trance. This year is Mbok Sutrinah's turn, who is beyond his consciousness mentioning Wiwin's name over and over. That means Wiwin is a virgin child who arrived in turn to be a Seblang dancer this year. But unexpectedly, Wiwin who was appointed by the Smooth Spirit as a Seblang dancer this year was not willing to participate. A young man whom I met in the arena said, "Wiwin, heng by ambi sir siranek !!". "Wiwin cannot (dance) with her girlfriend" he said while enjoying the Seblang show.

Since long time ago, Seblang dancers have always had a lineage with previous Seblang dancers. Because residents are afraid of the cancellation, at this sacred event, Salwati (who is still a sibling to Wiwin) was persuaded to replace it. With full of awareness, Salwati finally agreed. Regarding the consequences of Wiwin's unwillingness as a dancer this year, an elder said: "Kadung Ono paran-paran, ison heng ero jawanek !!" It means "If something is happened, I don't know!! ' Later there was an issue which saying about Wiwin experienced as "strange stress and depression". 


\section{CLOSING}

Based on the results of research on people's perceptions of behavior about the uniqueness of the Seblang Bakungan and Olehsari traditions, it can be concluded that the Seblang Bakungan Village is a ritual and is seen as a form of gratitude to God for village welfare, agricultural fertility, eliminating diseases, and keeping natural disasters away. Ritual Seblang-Olehsari is an attachment and awareness between humans and the universe, and creates a balanced relationship between humans and nature, so that a village condition is safe, awake, and protected from dangers. Seblang rituals are only carried out by the Osing community in Bakungan and Olehsari Villages, Glagah District, and as a guide to their ancestral heritage. Also in order to maintain and carry out the mandate of future generations, especially those with a line of springs and dancers. The role of the government in maintaining tradition through its power makes tradition as tourist attraction.

\section{ACKNOWLEDGEMENT}

The writers would like to thank all the supports given during the writing process of this article, especially students and lecturers at the Faculty of Teacher Training and Education, the Universitas of PGRI Banyuwangi who are dedicated in providing feedback and support for our project entitled ": Raditional Beliefs Seblang The Behavior Of The Osing Society Of Banyuwangi District, East Java Province "and friends from PGRI Banyuwangi University who gave suggestions and input in the publication and improvement of this article, especially the Head of LPPM, PGRI Banyuwangi University who has granted permission to carry out IN research.

\section{REFERENCES}

Asad, M. dkk. 2012.“. Nilai-nilai Keagamaan dalam Petuah Bijak, Puisi dan Peribahasa se Kawasan Timur Indonesia. Laporan Penelitian Balai Penelitian dan Pengembangan Agama Makassar. Bidang Lektur dan Khazanah Keagamaan.
Adibah, I. Z. 2019. Penyelidikan Sejarah Tentang Masyarakat Dan Budaya. Jurnal Madaniyah, 150-169.

Agur Mursidi, D. S. 2020. The Role Of Islamic Kingdom Characters In Nusantara In Maintaining The Independence Of The Republic Of Indonesia 1945-1950. International Jurnal of Education Schoolars, 105112.

Arifin, B. S. 2015. Psikologi Sosial. Bandung: Pustaka Setia.

Gerungan, W. (2004). Psikolog Sosial. Bandung: Refika Aditama.

Maran, R. R. 2007. Manusia dan Kebudayaan dalam Prespektif Ilmu Budaya Dasar. Jakarta: Rineka Cipta.

Moleong, L. J. 2015. Metode Penelitian Kualitatif. Bandung: Remaja Rosdakarya.

Muslim, A. 2016. Artikulasi Religi SajakSajak Basudara di Maluku. AlQalam, 19(2), 221-230.

Muslim, A. 2016. Kitorang Samua Basudara: Bijak Bestari di Bilik Harmoni. Harmoni, 15(2), 109-122.

Muslim, A. 2016. Religious and Cultural Harmonies In The Art Of Masamper. Analisa: Journal of Social Science and Religion, 1(2), 259-274.

Nasrullah, R. (2018). Komunikasi Antar Budaya: Di Era Budaya Siber. Jakarta: Kencana.

Priansa, D. J. (2017). Perilaku Konsumen dalam Bisnis Kontemporer. Bandung: Alfabeta.

Suciati. 2016. Psikologi Komunikasi Sebuah Tinjauan Teoritis dan Perspektifii Islam. Yogyakarta: Buku Litera.

Sugiyono. 2015. Metode Penelitian Kombinasi (Mix Methods). Bandung: Alfabeta.

Sukatman. 2009. Butir-butir Tradisi Lisan Indonesia Pengantar Teori dan pembelajarannya. Jember : LaksBang PRESSindo Yogyakarta.

Sukendar, M. U. 2017. Psikologi Komunkasi. Yogyakarta: CV Budi Utama.

Susanti, D. (2013). Mitos Asal-usul Buah Mengkudu Tanpa Biji di Lingkungan Makam Sunan Giri. Jember: Skripsi Jember: Fakultas Keguruan dan Ilmu Pendidikan Universitas Jember. 
